\title{
Digital tools for seaports geo-information support while climate change and Covid-19 pandemic
}

\author{
Valery Abramov ${ }^{1, *}$, Sergey Lukyanov ${ }^{1}$, Ekaterina Korinets ${ }^{1}$, Vladimir Bolshakov ${ }^{1}$, and \\ Tatiana Vekshina ${ }^{1}$ \\ ${ }^{1}$ Russian State Hydrometeorological University, 79, Voronezhskaya str., 192007, St.-Petersburg, \\ Russia
}

\begin{abstract}
In article, there are presented digital tools development results for geo-information support to seaports activity within Industry 4.0 period, when while climate change and covid-19 pandemic. In study, there are used methods of data bases constructing, web-technologies and virtual reality tools. Also, there are used Foresight technologies, theory of decision making under uncertainties and risk management. As digital tools, there is proposed to use digital online platforms, which integrate heterogeneous hardware and software resources with the use of web-technologies in distributed networks and wide application of cloud services. In study, there are used data bases and tools of geo-information digital online platform EOS, including its Land Viewer product. As study result, there is demonstrated usage of geoinformation support system for Russian seaport Ust-Luga. The research results presented in this article has significant scientific novelty and can be useful for private investors, public environmental organizations of the civil sector and state environmental control bodies.
\end{abstract}

\section{Introduction}

Recently, seaports activity (SPA) is functioning in Industry 4.0 period, and when while climate change and covid-19 pandemic. In this period, a wide range of information technologies are planning and implementing by many businesses [1-8]. Industry 4.0 leads to serious information technological changes in SPA [9, 10], including natural risks management (NRM) [11-17], which requires the development of new tools, including practical learning area [18].

The purpose of this article is to develop digitalization tools for geo-information support systems (GISS) to SPA. In paper, we describe the development results of digital tools for GISS to SPA within geo-information management (GIM) paradigm [19-22], in large environmental projects ([23-27] within environmental economics [28-32]. We paid significant attention to GISS within climate change $[33,34]$ and Covid-19 pandemic context, including the issues of information collection and processing [35-38]. Developed digital

\footnotetext{
*Corresponding author: val.abramov@mail.ru
} 
technologies for GISS to SPA while climate change and covid-19 pandemic, considered in this article, take these factors into account.

\section{Materials and Methods}

In research, we used Foresight technologies, theory of decision making under uncertainties, risk management approach, methods of data bases constructing, web-technologies and virtual reality tools. Also, we used Internet of things and big data technologies [19, 23, 39, 40]. From the point of view of geo-information management, geo-space is structured to allocate the interconnected components of the solution space [28]. While study, we used data bases and tools of geo-information digital online platform (GIDOP) EOS, including its Land Viewer (LV) product, https://eos.com/lv/, which allows limited open access to operate space images from the Landsat- 8 and Sentinel-2 satellite systems.

\section{Results}

As a result of performed using foresight technology research, we put forward the claim that in present conditions of climate change and Covid-19 pandemic, it would be advisable to develop seaports infrastructure with the aim of geopolitical risks management because of different sanctions and ecological restrictions in territorial waters of different states. Situation with NordStream-2 marine pipeline can be excellent example. Preference should be given to those seaports, where climate change leads to an improvement in their overall operating conditions, for example, a reduction in the timing of ice risks in their waters. As GISS basement, we propose to use the tools of GIDOP EOS https://eos.com/, including its Land Viewer (LV) product https://eos.com/lv/. As an example, we consider the Russian seaport of Ust-Luga. In figure 1, we show a general view of this seaport location on the Gulf of Finland's map (red rectangle).

Usually, Gulf of Finland are covered with ice for several months in winter. In figure 2, we present a satellite image of the Gulf of Finland on April 4, 1996, visualized with Natural Colors Application of LV product. In figure 2, ice covers near all East Gulf of Finland, including future Ust-Luga seaport waters (red rectangle), the construction of which began in 2000 and continues to this day. In figure 3, we present a satellite image of the East Gulf of Finland on February 6, 2020, visualized with Natural Colors Application of LV product. It is seen, that due to climate change in the East Gulf of Finland, there is a significant terms reduction of ice cover presence in the area of seaport Ust-Luga, which allows to allocate it as a priority object for development of sea port infrastructure of Russia. It is happening now, the Ust-Luga seaport is rapidly developing and it will be expanded to 1,600 hectares by the year of 2025 . 


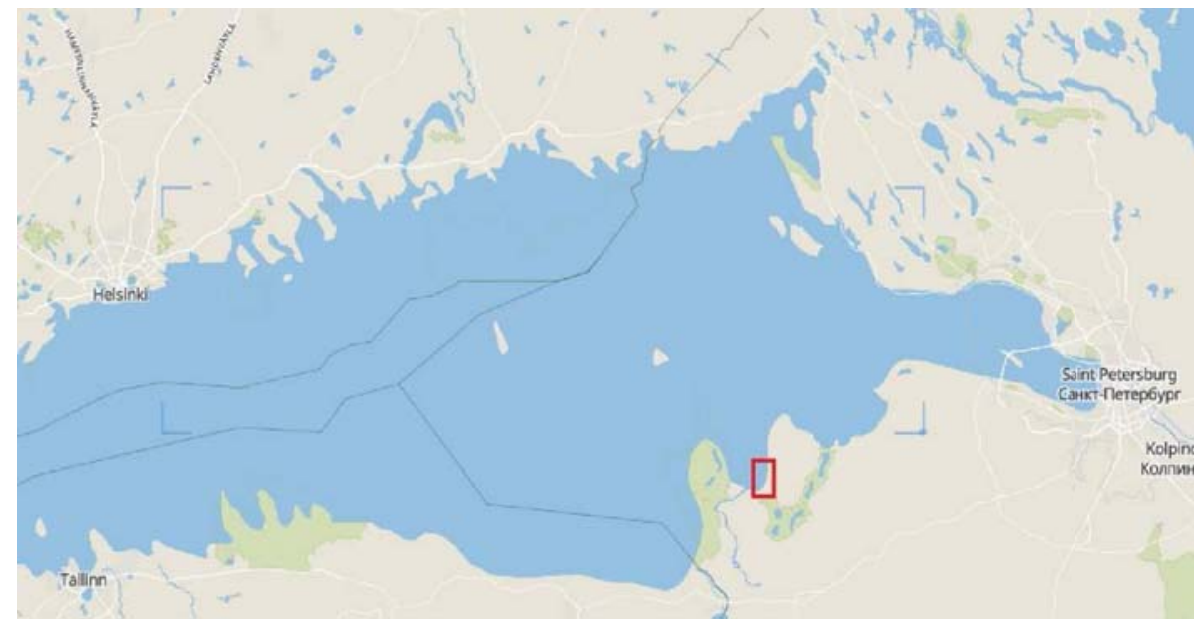

Fig. 1. General view of seaport Ust-Luga's location on the Gulf of Finland's map (red rectangle).

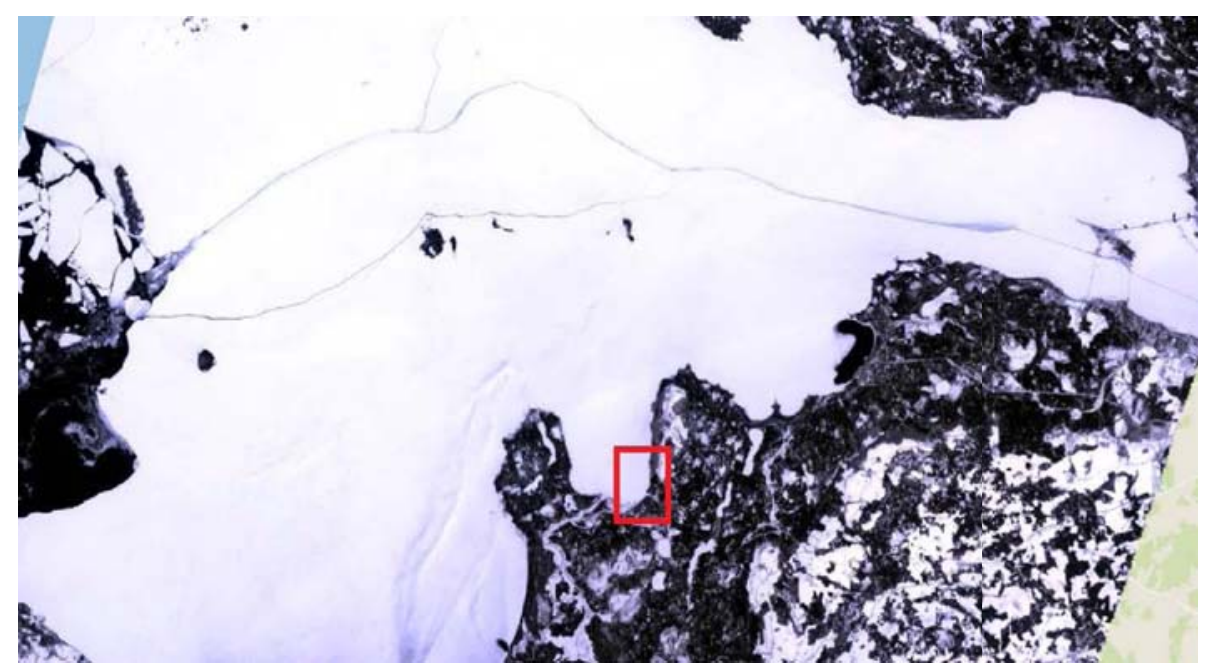

Fig. 2. East Gulf of Finland's space image on April 4, 1996, visualized with Natural Color Application of LV (red rectangular is Ust-Luga seaport area).

Currently, the port is carrying out intensive work on dredging the so-called approach channels and construction alluvial areas in the southern part of the port to the East of the Luga river mouth. The associated negative impact on the environment is the increased turbidity of the waters in the Bay and the violation of the natural habitat of bottom fauna. In figures 4 and 5, we present space images of the Luga Bay with Ust-Luga seaport on 23/09/2020 visualized with Natural Color Application of LV (red rectangular is Ust-Luga seaport area). 


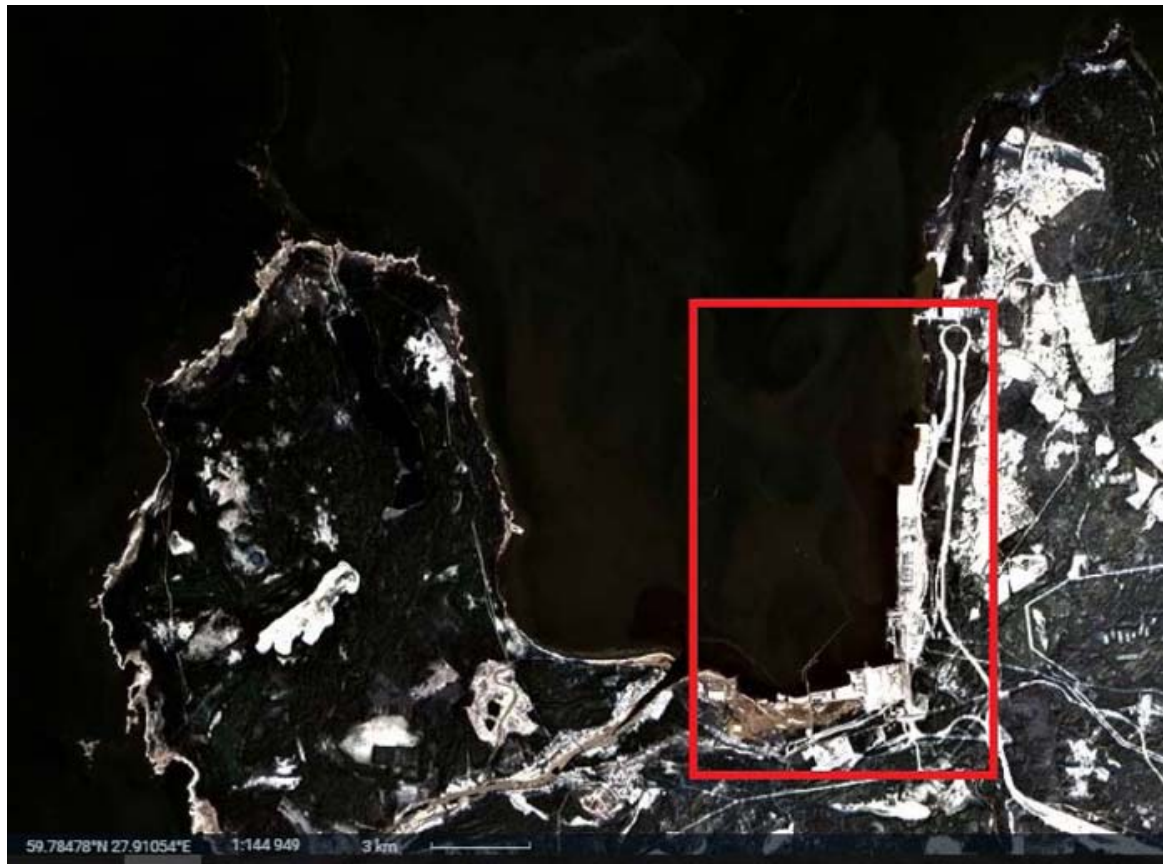

Fig. 3. Space image of the Luga Bay at Ust-Luga seaport on February 6, 2020, visualized with Natural Color Application of LV (red rectangular is Ust-Luga seaport area).

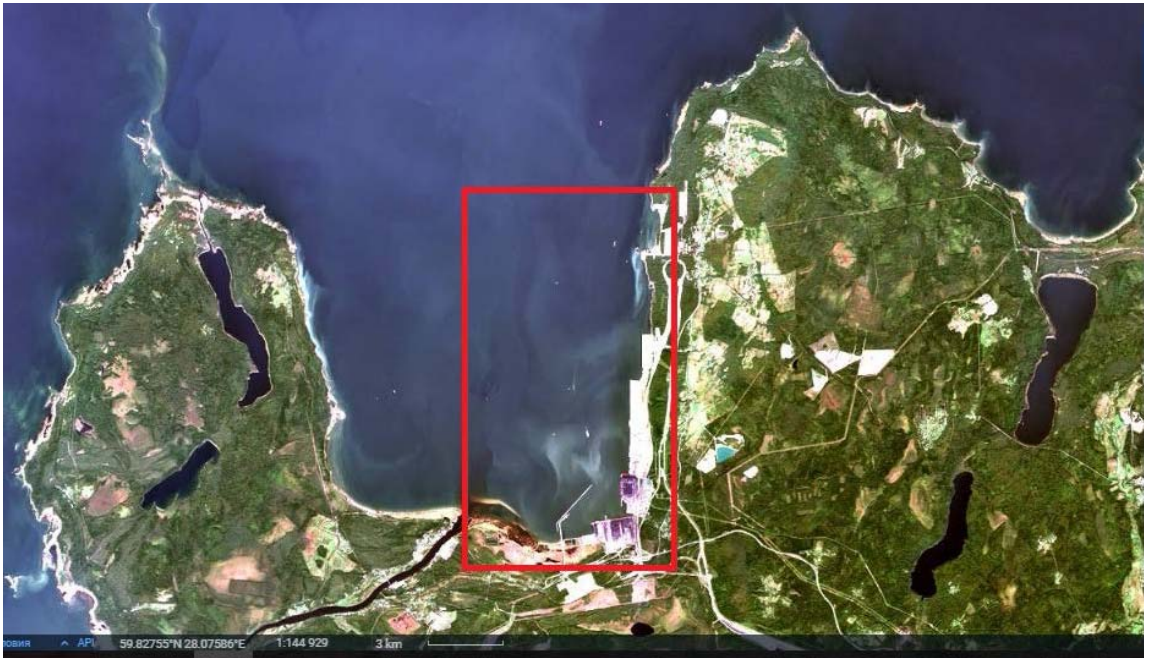

Fig. 4. Space image of the Luga Bay with Ust-Luga sea port on 23/09/2020 visualized with Natural Color Application of LV (red rectangular is Ust-Luga seaport area). 


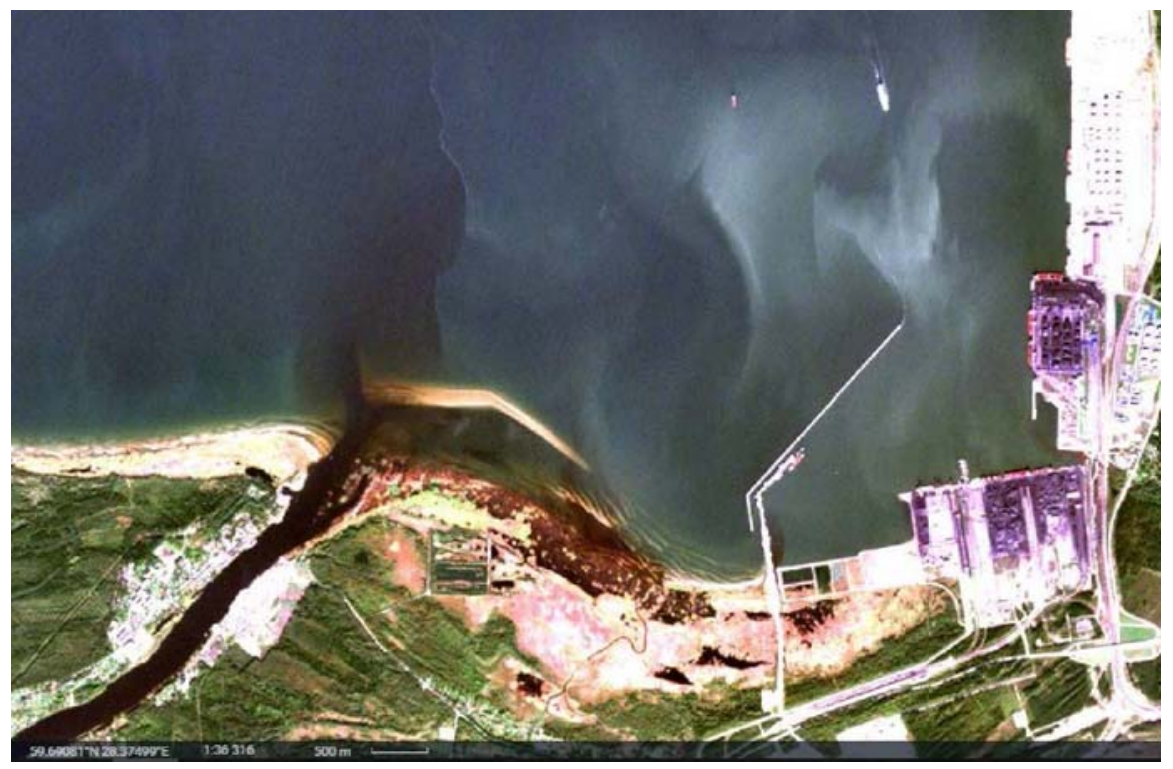

Fig. 5. Enlarged space image of the Luga Bay at Ust-Luga seaport on 23/09/2020 visualized with Natural Color Application of LV.

The use of special satellite image visualization applications as part of the proposed GISS made it possible to clearly identify the washed-up areas. The best results were achieved with the use of NDWI Application of LV (figure 6).

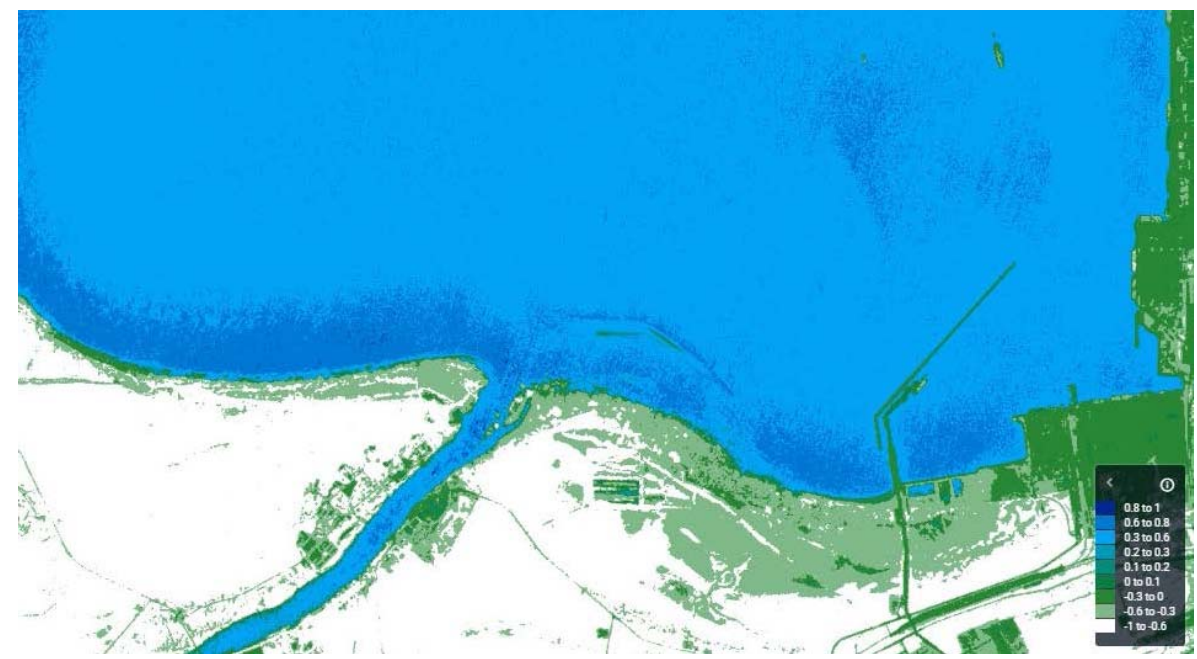

Fig. 6. Enlarged space image of the Luga Bay at Ust-Luga seaport on 23/09/2020 visualized with NDWI Application of LV.

As a result of the analysis of open mass media using the query system as part of the developed GISS, it was found that the above-mentioned dredging works are performed using the latest dredging vessel Kronshlot built in 2016 (figure 7). 


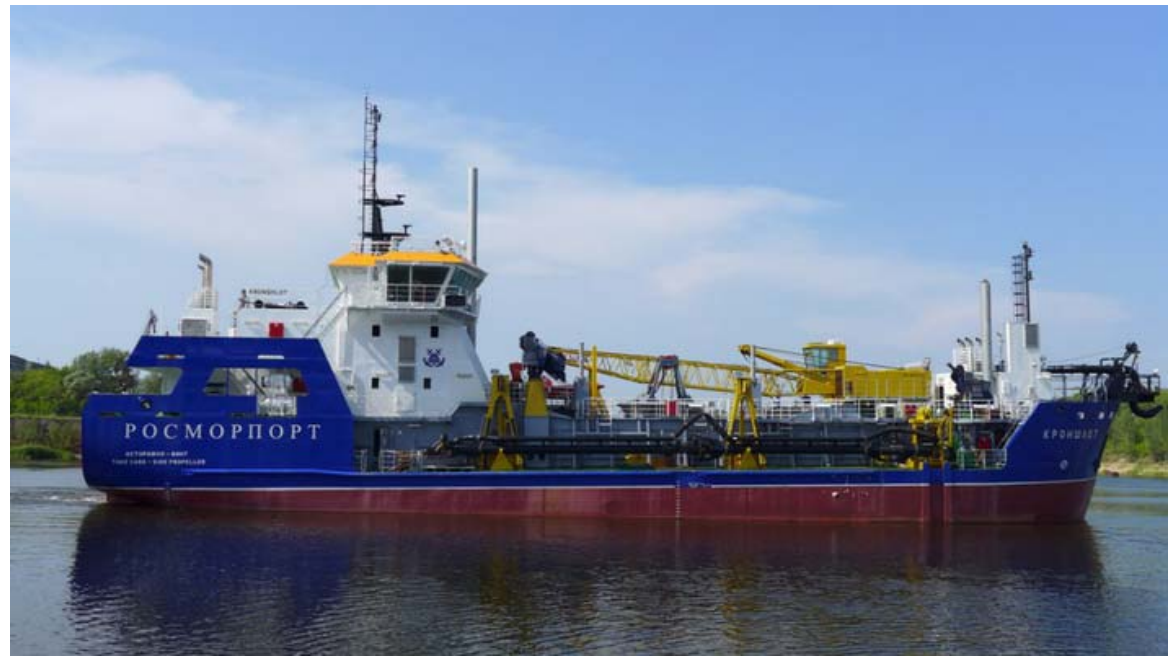

Fig. 7. Dredging vessel Kronshlot built in 2016.

We also established that dredging in the southern part of the seaport of Ust-Luga is expected to be carried out until the end of 2020, so increased turbidity in the Luga Bay will be observed further, until the end of these works. Note, discussion of the environmental consequences of the above-mentioned dredging operations in seaport of Ust-Luga is not task of this article.

Proposed here GISS for SPA can be used in educational and training purposes. Note, tasks of training will require a developed learning base within special geo-information systems (GIS) laboratory. It can be undergoing with virtual reality (VR) technologies (Popov, 2019), that can reduce total cost of learning process.

\section{Discussion}

Proposed here GISS for SPA can be used in educational and training purposes. Note, tasks of training will require a developed learning base within special geo-information systems (GIS) laboratory. It can be undergoing with virtual reality (VR) technologies [18]), that can reduce total cost of learning process.

\section{Conclusions}

In article, we describe results of digital tools development for geo-information support to SPA. While research, we used Foresight technologies, theory of decision, risk management, methods of data bases constructing, web-technologies and virtual reality tools. As study result, we suggest to use GIDOP EOS, including its LV product, as the main technological tools within GISS for SPA. We demonstrate possibilities of GISS on example for seaport Ust-Luga. As essential result, we propose to use developed GISS as basement for subsequent seaports, including educational and training purposes. The research results presented in this article has significant scientific novelty and can be useful for private investors, public environmental organizations of the civil sector and state environmental control bodies. They can be used in training and educational purposes, including development of Master's programs in environmental economics. 


\section{Acknowledgements}

We use platform https://www.researchgate.net/profile/Valery_Abramov2/ for preliminary discussion and data exchange while this research.

\section{References}

1. A. Sokolov, V. Abramov, E. Istomin, E. Korinets, V. Bolshakov, T. Vekshina, IOP Conference Series: Materials Science and Engineering 940(1), 012003 (2020)

2. N. Popov, V. Abramov, E. Istomin, T. Tatarnikova, E. Baykov, V. Zavgorodniy, IOP Conference Series: Materials Science and Engineering 940(1), 012013 (2020)

3. I.V. Ilin, A.V. Izotov, S.V. Shirokova, O.V. Rostova, A.I. Levina, Proceedings of 2017 20th IEEE International Conference on Soft Computing and Measurements, SCM 2017 7970732, 812-814 (2017)

4. A. Dubgorn, M.N. Abdelwahab, A. Borremans, I. Zaychenko, Proceedings of the 33rd International Business Information Management Association Conference, IBIMA 2019: Education Excellence and Innovation Management through Vision 2020 (2019)

5. Poljanskihh, A., Levina, A., Dubgorn, A. MATEC Web of Conferences 193, 05065 (2018)

6. S.V. Trunin, S.V. Lukyanov, E.A. Baikov et al, Proceedings of 34th IBIMA Conference. Vision 2025: Education Excellence and Management of Innovations Through Sustainable Economic Competitive Advantage (2019)

7. N.S. Frolova, V.M. Abramov, E.P. Istomin, N.N. Popov, M.B. Shilin, S.V. Lukyanov, V.A. Golosovskaya, D.V. Drabenko, Proceedings of 34th IBIMA Conference. Vision 2025: Education Excellence and Management of Innovations Through Sustainable Economic Competitive Advantage (2019)

8. S.V. Lukyanov, V.M. Abramov, A.S. Averkiev, A.E. Rybalko, Yu.A. Tatarenko, N.S. Frolova, O.I. Shevchuk, Proceedings of the 33rd International Business Information Management Association Conference, IBIMA 2019: Education Excellence and Innovation Management through Vision 2020 (2019)

9. S. Maydanova, I. Ilin, A. Lepekhin, Proceedings of the 33rd International Business Information Management Association Conference, IBIMA 2019: Education Excellence and Innovation Management through Vision 2020 (2019)

10. V. Orlova, I. Ilin, S. Shirokova, MATEC Web of Conferences 193 (2018)

11. S. Berboushi, J. Lednova, G. Gogoberidze, V.M. Abramov, L.N. Karlin, 14th International Multidisciplinary Scientific GeoConference Surveying Geology and Mining Ecology Management, SGEM Bulgaria 1(5), 161-168 (2014)

12. V.A. Drabenko, E.P. Istomin, V.M. Abramov et al, Proceedings of 34th IBIMA Conference: Vision 2025: Education Excellence and Management of Innovations Through Sustainable Economic Competitive Advantage (2019)

13. A. Ershova, M. Shilin, V. Zhigulsky, A. Chusov, V. Abramov, T. Bagrova, N. Popov, IEEE/OES Baltic International Symposium (2018) DOI: 10.1109/BALTIC.2018.8634858

14. J.A. Garcia, V.M. Abramov, E.P. Istomin, 18th International Multidisciplinary Scientific GeoConference Surveying Geology and Mining Ecology Management, SGEM Bulgaria 18(2.2), 261-268 (2018) 
15. A.V. Isaev, G.G. Gogoberidze, N.N. Popov, V.M. Abramov, S.V. Berboushi, 15th International Multidisciplinary Scientific GeoConference Surveying Geology and Mining Ecology Management, SGEM Bulgaria 1(4), 953-960 (2015)

16. E.P. Istomin, V.G. Burlov, V.M. Abramov, A.A. Fokicheva, A.G. Sokolov, 18th International Multidisciplinary Scientific GeoConference Surveying Geology and Mining Ecology Management, SGEM Bulgaria 18(2.2), 377-384 (2018)

17. M.B. Shilin, V.M. Abramov, I.V. Aleshi, V.G. Burlov, A. Chusov, E.P. Istomin, A.G. Sokolov, Proceedings of the 33rd International Business Information Management Association Conference, IBIMA 2019: Education Excellence and Innovation Management through Vision 2020 (2019)

18. N.N. Popov, V.M. Abramov, E.M. Korinets, E.P. Istomin, A.G. Sokolov, V.A. Bolshakov, T.V. Vekshina, Proceedings of 34th IBIMA Conference: 13-14 November 2019, Madrid, Spain. Vision 2025: Education Excellence and Management of Innovations Through Sustainable Economic Competitive Advantage (2019)

19. E.A. Yaily, V.M. Abramov, E.P. Istomin, S.I. Bidenko, V.V. Novikov, S.I. Bidenko, 19th International Multidisciplinary Scientific GeoConference Surveying Geology and Mining Ecology Management, SGEM, Bulgaria 19(2.1), 793-799 (2019)

20. A.A. Fokicheva, E.P. Istomin, A.G. Sokolov, V.M. Abramov, N.N. Popov, 16th Informatics, geoinformatics and remote sensing conference proceedings, International Multidisciplinary Scientific GeoConference Surveying Geology and Mining Ecology Management, SGEM Bulgaria 4(2), 601-608 (2016)

21. J.A. Malakhova, G.G. Gogoberidze, L.N. Karlin, V.M. Abramov, J.A. Lednova, 14th International Multidisciplinary Scientific GeoConference SGEM 2014 Bulgaria 3(5), 253-260 (2014)

22. J. Lednova, G. Gogoberidze, L. Karlin, V. Abramov, IEEE/OES Baltic International Symposium 2014, BALTIC $2014 \mathbf{6 8 8 7 8 4 0}$ (2014)

23. A.N. Popova, V.M. Abramov, E.P. Istomin, A.G. Sokolov, N.N. Popov, A.I. Levina, Proceedings of the 33rd International Business Information Management Association Conference, IBIMA 2019: Education Excellence and Innovation Management through Vision 2020 (2019)

24. E. Rumyantseva, G. Gogoberidze, V.M. Abramov, N. Rodin, G. Vladimirova, 17th International Multidisciplinary Scientific GeoConference Surveying Geology and Mining Ecology Management, SGEM Bulgaria 17(52), 921-928 (2017)

25. V.A. Zhigulsky, M.B. Shilin, A.A. Ershova, V.M. Abramov, 18th International Multidisciplinary Scientific GeoConference Surveying Geology and Mining Ecology Management, SGEM, Bulgaria 18(5.1), 423- 430 (2018)

26. N.N. Popov, L.N. Karlin, J.A. Lednova, V.M. Abramov, G.G. Gogoberidze, 14th International Multidisciplinary Scientific GeoConference Surveying Geology and Mining Ecology Management, SGEM Bulgaria 2(4), 313-320 (2014)

27. O.N. Mandryka, V.M. Abramov, M.B. Shilin, A.A. Ershova, Yu.L. Matveev, A.N. Chusov, N.N. Popov, Proceedings of the 33rd International Business Information Management Association Conference, IBIMA 2019: Education Excellence and Innovation Management through Vision 2020 (2019)

28. S.I. Bidenko, E.P. Istomin, V.G. Burlov, V.M. Abramov, A.G. Sokolov, 19th International Multidisciplinary Scientific GeoConference Surveying Geology and Mining Ecology Management, SGEM Bulgaria 19(5.3), 139-145 (2019) 
29. V.A. Golosovskaya, L.N. Karlin, V.M. Abramov, G.G. Gogoberidze, 14th International Multidisciplinary Scientific GeoConference Surveying Geology and Mining Ecology Management, SGEM Bulgaria 1(3), 495-501 (2014)

30. L.N. Karlin, J.A. Lednova, J.A. Malakhova, V.M. Abramov, G.G. Gogoberidze, S.V. Berboushi, 14th International Multidisciplinary Scientific GeoConference Surveying Geology and Mining Ecology Management, SGEM Bulgaria 2(4), 599-606 (2014)

31. L.N. Karlin, V.M. Abramov, A.A. Ovsiannikov, Oceanology 49(3), 327-330 (2009)

32. N.N. Popov, R.I. Bachiev, V.M. Abramov, 16th International Multidisciplinary Scientific GeoConference Surveying Geology and Mining Ecology Management, SGEM Bulgaria 4(2), 323-330 (2016)

33. A.V. Bournashov, L.V. Alexandrova, L.N. Karlin, V.M. Abramov, G.G. Gogoberidze, 14th International Multidisciplinary Scientific GeoConference Surveying Geology and Mining Ecology Management, SGEM Bulgaria 2(3), 661-668 (2014)

34. G.G. Gogoberidze, L.V. Alexandrova, N.N. Popov, V.M. Abramov, L.N. Karlin, 15th International Multidisciplinary Scientific GeoConference Surveying Geology and Mining Ecology Management, SGEM Bulgaria 2(3), 701-708 (2015)

35. A.A. Fokicheva, E.P. Golosovskaya, V.M. Abramov, E.P. Istomin, A.G. Sokolov, A.I. Levina, Proceedings of the 33rd International Business Information Management Association Conference, IBIMA 2019: Education Excellence and Innovation Management through Vision 2020 (2019)

36. O. Khaimina, L. Karlin, G. Gogoberidze, J. Lednova, V.M. Abramov, A. Isaev, 14th International Multidisciplinary Scientific GeoConference Surveying Geology and Mining Ecology Management, SGEM Bulgaria 2(3), 645-652 (2014)

37. S. Krasnov, S. Sergeev, E. Zotova, N. Grashchenko, E3S Web of Conferences 110, 02052 (2019)

38. T.M. Tatarnikova, I.N. Dziubenko, Wave Electronics and its Application in Information and Telecommunication Systems (WECONF) (2018)

39. A.I. Klimin, N.V. Pavlov, A.M. Efimov, Z.L. Simakova, Proceedings of the 31 st International Business Information Management Association Conference, IBIMA 2018: Innovation Management and Education Excellence through Vision 2020 (2018)

40. A.I. Levina, A.S. Dubgorn, O.Y. Iliashenko, Proceedings - 2017 European Conference on Electrical Engineering and Computer Science, EECS 2017 (2018)

41. IBIMA 2019: Education Excellence and Innovation Management through Vision 2020 (Management Association Conference, 2019) 